\title{
Neural Foundations of Action-related Language: Studies in Parkinson's Disease
}

\author{
Hareketle İlişkili Dilin Nöral Temelleri: Parkinson Hastalı̆̆ında Yapılan Çalışmalar
}

\author{
Ece Bayram¹, (1) Muhittin Cenk Akbostanc1 1,2 \\ ${ }^{1}$ Ankara University Institute of Health Sciences, Department of Interdisciplinary Neuroscience, Ankara, Turkey \\ ${ }^{2}$ Ankara University Faculty of Medicine, Department of Neurology, Ankara, Turkey
}

\begin{abstract}
Parkinson's disease (PD), which is one of the most common neurodegenerative disorders, is a disorder that affects quality of life due to non-motor symptoms in addition to motor symptoms. The non-motor symptoms of this disease vary greatly and affect patients starting from early stages. These symptoms also include language deficits. Besides motor language disorders such as hypophonia and dysarthria, which are common in PD, deficits in morphosyntax, semantics, and understanding metaphors have been reported. Various studies have also shown deficits in action language in PD, in which the ability of action is affected. Although language deficits are thought to be caused by cognitive deficits in this disease, there are studies showing language deficits being independent of cognitive deficits. These language deficits in PD, caused by basal ganglia dysfunctions, may provide valuable information in determining brain areas related to language. In this review, we aimed to assess action language deficits in PD and to evaluate the location of action language in the brain in light of this disorder.
\end{abstract}

Keywords: Parkinson's disease, embodiment, action language

$\ddot{O} \mathbf{z}$

En sık görülen nörodejeneratif hastalıklardan biri olan Parkinson hastalığ ${ }_{1}(\mathrm{PH})$ motor semptomların yanı sıra yol açtı ̆̆ 1 non-motor semptomlar nedeniyle yaşam kalitesini etkileyen bir bozukluktur. Hastalıkta görülen non-motor semptomlar çok çeşitli olup erken evrelerden itibaren hastaları etkiler. Bunlardan biri de dil bozukluklarıdır. Parkinson hastalarında sık görülen hipofoni, dizartri gibi motor dil bozukluklarının yanı sıra morfo-sentaktik, semantik ve mecaz algılamada da bozulmalar olduğu bildirilmiştir. Çeşitli çalışmalar hareket yetisini etkileyen PH'de aynı zamanda hareket içeren dilde de bozulmalar olduğunu göstermiştir. Hastalıktaki dil bozukluklarının bilişsel bozukluklardan kaynaklandığı düşünülse de hastalarda bilişsel bozukluklardan bağımsız olarak dil bozukluğunun olduğunu gösteren çalışmalar da mevcuttur. Bazal ganglionlardaki hasar nedeniyle oluşan PH'de görülen bu dil bozuklukları dille ilişkili beyin alanlarının belirlenmesi açısından değerli bilgiler sunabilmektedir. Bu derlemede PH'de görülen hareket içeren dil bozuklukları ve bu bozukluklar 1 şı̆̆ında hareket içeren dilin beyindeki yerleşiminin değerlendirilmesi amaçlanmıştır.

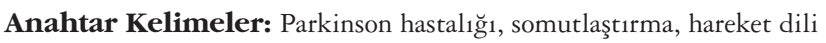

Address for Correspondence/Yazışma Adresi: Ece Bayram MD, Ankara University Institute of Health Sciences, Department of Interdisciplinary Neuroscience, Ankara, Turkey

Phone: +90 5456652977 E-mail: bayramece@windowslive.com ORCID ID: orcid.org/0000-0002-6875-4242

Received/Geliş Tarihi: 09.06.2016 Accepted/Kabul Tarihi: 20.02.2017

${ }^{\circ}$ Copyright 2018 by Turkish Neurological Society

Turkish Journal of Neurology published by Galenos Publishing House. 


\section{Introduction}

Parkinson's disease (PD) is the most common neurodegenerative disorder after Alzheimer's disease. Four million patients with PD were reported in 2007 all around the world (1). Its prevalence is 202/100000 in Turkey (2). Although the cause of PD is unknown, it is believed that a combination of genetic and environmental factors plays role in its pathogenesis.

Currently, there are no gold standard tests for the diagnosis of PD. The diagnosis is made through neurologic examination and anamnesis, and motor symptoms are kept in the forefront for diagnosis. Bradykinesia, resting tremor, rigidity, and disturbances of posture and walking are the characteristic motor findings of PD. However, patients with PD can have non-motor symptoms besides motor symptoms. Non-motor symptoms can promote early diagnosis of the disease and can affect patients' quality of life more than motor symptoms (3). These symptoms are neuropsychiatric disorders such as mood disorders and cognitive decline; autonomic dysfunction, such as constipation and ortostatic hypotension; sleep disorders; sensorial disturbances; reduced ability to smell; fatigue; and pain (3).

Speech and language dysfunctions have been reported in PD. Although dysarthria and hypophonia are rather common, there are also language disturbances that are not associated with motor functions. These disturbances include morphosyntactic, lexicalsemantic, and discourse-level processes. Studies show disturbances in language functions including understanding long and complex sentences, action word recognition, action word naming and producing, and metaphor comprehension (4). Although some of these disturbances are associated with impairment in cognitive processes including executive functions, working memory, and selective attention, some studies showed that language disturbances were independent from cognitive decline (4). Such studies may be helpful in showing the role of basal ganglia (BG) on language and investigating the motor theory of language. Also, early recognition of action-related language dysfunction can be useful in the early diagnosis and treatment of PD.

According to the Embodied Cognitive Theory, cognitive representations containing meanings about different body parts are associated with brain networks associated with that part of the body (5). The motor theory of language based on the Embodied Cognitive Theory suggests that action-related language is located in the areas of the brain related with action. Indeed, the activation of the primary motor and premotor cortex while processing words or sentences that describe action including movement of the mouth, hand or leg supports this theory (4). In contrast, there are also studies showing that activation of cortical motor areas that have somatotopic organization with action-related language does not follow somatotopic organization (6). Motor cortex lesions do not cause disturbances in the processing of verbs, whereas premotor cortex lesions do, which makes us question this theory $(7,8,9)$. The findings of these studies suggest that other systems and areas in the brain besides the cortical motor system play a role in action-related language. The motor system is not limited to the level of cortex and therefore, the effects of subcortical areas and subcortico-cortical network on action-related language should also be considered. In this context, PD with impairment in cortical and subcortical functions can provide an important backdrop to investigate the effects of the cortical and subcortical network on action-related language.

We reviewed studies on action-related language deficits in PD to evaluate the brain localization of action-related language. First, we briefly discuss cognitive disturbances that are considered to underlie the disturbance of action-related language in PD. We very briefly mention speech disturbances due to motor problems, which are common in PD, because they are beyond the scope of this review. We review studies on action-related language in PD in detail. Finally, we review the role of impaired BG in PD in action-related language and the organization of action-related language in the brain.

\section{Cognitive Disturbances in Parkinson's Disease}

Cognitive disturbances affect at least $75 \%$ of patients with PD within 10 years of diagnosis (10). The most common cognitive dysfunctions are related to visual-spatial functions, attention, and executive functions (11). These features differentiate cognitive impairment in PD from other neurodegenerative disorders such as Alzheimer's disease, in which memory problems are common in the early stage (11). These disturbances occur in the early period of $\mathrm{PD}$ and become more apparent in time and eventually progress to dementia (12). Therefore, an integrated approach in treatment should be adopted and patients should be evaluated for the presence of cognitive symptoms besides motor symptoms. Aarsland et al. (13) reported that patients with early PD who did not take any medication had two times more cognitive impairment compared with healthy controls.

In patients with $\mathrm{PD}$ without dementia, visual-spatial impairment is not considered as a pure disorder and is thought to originate from motor and/or executive dysfunction. However, the persistent presence of visuospatial impairment while performing tasks that do not require motor and/or executive functions contradicts this theory (14). Deterioration in the picture naming task, which is commonly used in action-related language studies in patients with PD, can be attributed to visuospatial impairments. It is expected that disturbance in visual perception in PD could lead to deterioration in the perception of pictures, which could cause an increase in naming errors.

PD does not cause a deficit in all attention domains. Vigilance and sustained attention are often preserved in PD. Patients exhibit worse performance in tasks related to implicit attention, divided attention, processing speed, and directing resources of attention internally $(15,16,17)$. However, deterioration in implicit and divided attention is thought to be secondary to deterioration in inhibitory mechanisms.

Cognitive functions such as planning, cognitive flexibility, autonomic response inhibition, holding, and processing and managing data in the working memory are executive functions. Various executive dysfunctions are reported in early PD (18). Studies have shown disturbances in cognitive functions including working memory, planning, observation of response, cognitive flexibility, trial and error learning, and attention control in patients with PD with or without dementia (14). However, these disturbances, which are affected by intelligence, age, and education and treatment, present in different ways in each patient (18). Executive function and attention deficits are considered to occur first, and other cognitive impairments are considered to be mainly caused by these initial deficits. Therefore, 
the role of executive functions in tasks that evaluate language functions should not be ignored, and the results of these tests should not be considered as only representing language.

Besides these deficits, memory problems involving delayed recall, temporal sorting, and conditional learning can occur in PD (14). Memory disturbances are thought to originate from executive dysfunction in PD (19). Long- term memory is preserved in PD, and short-term memory deficits have been reported (20). Shortterm visual memory impairment is correlated with disease severity and motor performance, whereas short-term verbal memory is preserved (21). Declarative and procedural memory disturbances are more common in patients with PD compared with healthy controls (22). Coding and recognition are preserved in PD, whereas initiating and resuming search strategies can be impaired (14). Thus, using tasks that require a search strategy in language studies may result in false deterioration of language functions.

Language disturbances due to motor problems are very common in patients with PD (16). Ninety percent of patients with PD present with disturbances in voice and/or articulation during the disease (23). Specific speech for PD is characterized by monotonous speech and decreased sound volume, speaking with short sentences, short and fast speaking. Most of these speech problems are caused by hypokinesia and rigidity (24). Patients often complain of hoarseness and others not comprehending their speech. Patients also have difficulties in production and comprehension besides speech disturbances due to motor problems. These difficulties are thought to be caused by cognitive impairment in PD but they may also be sole language deficits. Deteriorations in tasks involving processes such as naming, production of words using semantic and/ or phonemic clues, understanding sentences and grammar have been reported (14). These deteriorations can be seen at the level of words, sentences or long conversations. Dysfunctions at the level of words are associated with executive dysfunction, and dysfunctions at the level of sentences and long conversations are associated with attention deficits $(25,26,27)$. Disturbances in syntactic processes in $\mathrm{PD}$ are associated with cognitive disturbances including working memory and data processing (28).

\section{Action-related Language Disturbances in Parkinson's Disease}

Various studies have shown that the motor system plays an import role in understanding and producing verbs. Studies using different imaging modalities showed that fast-triggered motor activations were functionally related with comprehension in a somatotopic manner after reading or hearing verbs (29,30). Outputs from BG to frontal motor areas are diminished due to a decrease of dopamine in the striatum in $\mathrm{PD}$, which causes dysregulation in the presupplementary motor area, supplementary motor area, primary motor cortex, and ventral premotor cortex (31). PD can lead to finding the localization of action-related language in the brain. All studies that will be discussed in this section are summarized in Table 1.

Table 1. Action related language studies in patients with Parkinson's disease

\begin{tabular}{|c|c|c|c|}
\hline Author & Participants & Task & Findings \\
\hline $\begin{array}{l}\text { Bertella et al. } \\
\text { (32) }\end{array}$ & $\begin{array}{l}22 \text { early stage PD } \\
\text { patients, } 20 \text { healthy } \\
\text { controls }\end{array}$ & $\begin{array}{l}\text { Object and action picture } \\
\text { naming }\end{array}$ & Action naming was worse in PD patients \\
\hline Peran et al. (33) & $\begin{array}{l}34 \text { PD patients, } 34 \\
\text { healthy controls }\end{array}$ & Noun and verb production & Action production was worse in PD patients \\
\hline $\begin{array}{l}\text { Signorini and } \\
\text { Volpato (34) }\end{array}$ & $\begin{array}{l}20 \text { PD patients, } 20 \\
\text { healthy controls }\end{array}$ & $\begin{array}{l}\text { Cognitive, verbal fluency, } \\
\text { object and action naming tasks }\end{array}$ & Action fluency was worse in PD patients \\
\hline $\begin{array}{l}\text { Cotelli et al. } \\
(35)\end{array}$ & $\begin{array}{l}32 \text { PD patients, } 15 \\
\text { healthy controls }\end{array}$ & $\begin{array}{l}\text { Object and action picture } \\
\text { naming }\end{array}$ & $\begin{array}{l}\text { Action and object naming was worse in PD patients; } \\
\text { action naming was worse than object naming in PD } \\
\text { patients }\end{array}$ \\
\hline $\begin{array}{l}\text { Boulenger et al. } \\
\text { (36) }\end{array}$ & $\begin{array}{l}10 \text { PD patients, } 10 \\
\text { healthy controls }\end{array}$ & $\begin{array}{l}\text { Lexical judgments with priming } \\
\text { effect involving nouns and } \\
\text { verbs }\end{array}$ & $\begin{array}{l}\text { Priming effect was not observed in "off" period; } \\
\text { priming effect was observed in "on" period similar to } \\
\text { controls }\end{array}$ \\
\hline $\begin{array}{l}\text { Castner et al. } \\
(37)\end{array}$ & $\begin{array}{l}8 \text { PD patients with } \\
\text { bilateral STN-DBS, } 15 \\
\text { healthy controls }\end{array}$ & Noun and verb production & $\begin{array}{l}\text { During the "on" condition more mistakes in verb } \\
\text { production in PD patients; during the "off" condition } \\
\text { more mistakes in noun-noun and verb-verb conditions }\end{array}$ \\
\hline $\begin{array}{l}\text { Crescentini et } \\
\text { al. (38) }\end{array}$ & $\begin{array}{l}20 \text { PD patients; } 20 \\
\text { healthy controls }\end{array}$ & Noun and verb production & $\begin{array}{l}\text { Verb production was worse in PD patients; } \\
\text { deterioration in verb production was correlated with } \\
\text { executive dysfunction }\end{array}$ \\
\hline Peran et al. (39) & 14 PD patients & $\begin{array}{l}\text { Object picture naming, verb } \\
\text { production, fMRI }\end{array}$ & $\begin{array}{l}\text { Verb production was worse; activation was more } \\
\text { obvious in prefrontal cortex, Broca area and anterior } \\
\text { cingulate cortex during verb production }\end{array}$ \\
\hline $\begin{array}{l}\text { Rodriguez- } \\
\text { Ferreiro et al. } \\
\text { (40) }\end{array}$ & $\begin{array}{l}28 \text { PD patients, } \\
28 \text { patients with } \\
\text { Alzheimer's disease, } 28 \\
\text { healthy controls }\end{array}$ & $\begin{array}{l}\text { Object and action picture } \\
\text { naming }\end{array}$ & $\begin{array}{l}\text { Picture naming was worse in PD and Alzheimer's } \\
\text { disease; action naming was worse than object naming } \\
\text { only in PD patients }\end{array}$ \\
\hline $\begin{array}{l}\text { Herrera et al. } \\
(41)\end{array}$ & $\begin{array}{l}20 \text { PD patients, } 20 \\
\text { healthy controls }\end{array}$ & Verbal fluency & $\begin{array}{l}\text { Phonemic and verb fluency were worse in "off" period } \\
\text { in PD patients }\end{array}$ \\
\hline
\end{tabular}


Table 1 . Continued

\begin{tabular}{|c|c|c|c|}
\hline Author & Participants & Task & Findings \\
\hline $\begin{array}{l}\text { Herrera et al. } \\
(42)\end{array}$ & $\begin{array}{l}49 \text { PD patients, } 19 \\
\text { healthy controls }\end{array}$ & $\begin{array}{l}\text { Action picture naming with } \\
\text { low or high motor contents }\end{array}$ & $\begin{array}{l}\text { More deterioration in action naming with high action } \\
\text { content than with low action content in PD patients }\end{array}$ \\
\hline $\begin{array}{l}\text { Herrera and } \\
\text { Cuetos }(43)\end{array}$ & $\begin{array}{l}20 \text { PD patients, } 15 \\
\text { healthy controls }\end{array}$ & $\begin{array}{l}\text { Action picture naming with } \\
\text { low or high motor contents }\end{array}$ & $\begin{array}{l}\text { More slowing in action naming with high action } \\
\text { content in "off" period compared with in "on" period } \\
\text { in PD patients }\end{array}$ \\
\hline $\begin{array}{l}\text { Silveri et al. } \\
(44)\end{array}$ & $\begin{array}{l}12 \text { PD patients with } \\
\text { bilateral STN-DBS, } 12 \\
\text { healthy controls }\end{array}$ & $\begin{array}{l}\text { Object and action picture } \\
\text { naming, reading }\end{array}$ & $\begin{array}{l}\text { Deterioration in naming in PD patients, slowing in } \\
\text { action naming, during the "on" condition improvement } \\
\text { in action naming, slowing in reading in PD patients }\end{array}$ \\
\hline $\begin{array}{l}\text { Fernandino et } \\
\text { al. }(45)\end{array}$ & $\begin{array}{l}20 \text { PD patients, } 22 \\
\text { healthy controls }\end{array}$ & $\begin{array}{l}\text { Lexical judgments and } \\
\text { semantic similarity test } \\
\text { involving abstract and action } \\
\text { verbs }\end{array}$ & $\begin{array}{l}\text { Worse performance in both tasks in action verbs in PD } \\
\text { patients }\end{array}$ \\
\hline $\begin{array}{l}\text { Fernandino et } \\
\text { al. }(46)\end{array}$ & $\begin{array}{l}20 \text { PD patients, } 21 \\
\text { healthy controls }\end{array}$ & Sentence comprehension & $\begin{array}{l}\text { More slowing in sentences containing real action verbs } \\
\text { and idiomatic verbs compared with abstract verbs in } \\
\text { PD patients }\end{array}$ \\
\hline $\begin{array}{l}\text { Ibanez et al. } \\
(47)\end{array}$ & $\begin{array}{l}17 \text { early stage PD } \\
\text { patients, } 15 \text { healthy } \\
\text { controls }\end{array}$ & ACE & Decrease in ACE in PD patient \\
\hline $\begin{array}{l}\text { Kemmerer et } \\
\text { al. ( } 48 \text { ) }\end{array}$ & $\begin{array}{l}10 \text { PD patients, } 10 \\
\text { healthy controls }\end{array}$ & $\begin{array}{l}\text { Semantic similarity test with } \\
\text { and without action containing } \\
\text { verbs }\end{array}$ & Slowing in both tasks in PD patients \\
\hline Peran et al. (49) & $8 \mathrm{PD}$ patients & $\begin{array}{l}\text { Object picture naming, verb } \\
\text { production, imagining action in } \\
\text { mind; fMRI }\end{array}$ & $\begin{array}{l}\text { More mistakes in verb production than object } \\
\text { production. Verb production caused more activation } \\
\text { in left prefrontal cortex and left precuneus compared } \\
\text { with object naming and imagining action in mind } \\
\text { caused more activation in bilateral prefrontal cortex } \\
\text { and bilateral parietooccipital junction compared } \\
\text { with object naming. Difference in prefrontal areas } \\
\text { between verb producing and object naming tasks and } \\
\text { in thalamus and premotor areas between imagining } \\
\text { action in mind and object naming in ON compared } \\
\text { with OFF }\end{array}$ \\
\hline $\begin{array}{l}\text { Cardona et al. } \\
(50)\end{array}$ & $\begin{array}{l}10 \text { patients with } \\
\text { neuromyelitis optica, } \\
10 \text { patients with acute } \\
\text { transverse myelitis } \\
\text { and } 10 \text { early stage PD } \\
\text { patients }\end{array}$ & $\mathrm{ACE}$ & $\begin{array}{l}\text { Decrease in ACE in PD patient; ACE and action } \\
\text { containing verb tests were correlated }\end{array}$ \\
\hline $\begin{array}{l}\text { Bocanegra et } \\
\text { al. (51) }\end{array}$ & $\begin{array}{l}40 \text { PD patients, } 40 \\
\text { healthy controls }\end{array}$ & $\begin{array}{l}\text { Executive function tests, } \\
\text { evaluation of Boston diagnostic } \\
\text { aphasia, identifying verb and } \\
\text { object from picture }\end{array}$ & $\begin{array}{l}\text { Deterioration in executive functions, syntactic analysis, } \\
\text { verb naming, verb and object identification in PD } \\
\text { patients; deterioration in verb naming and verb } \\
\text { identification was not related with executive functions }\end{array}$ \\
\hline $\begin{array}{l}\text { Melloni et al. } \\
\text { (52) }\end{array}$ & $\begin{array}{l}14 \text { PD patients, } 16 \\
\text { healthy controls }\end{array}$ & $\begin{array}{l}\text { ACE; cortical recordings of the } \\
\text { motor potential, functional } \\
\text { connectivity measures, and } \\
\text { structural analysis of the basal } \\
\text { ganglia through voxel-based } \\
\text { morphometry }\end{array}$ & $\begin{array}{l}\text { Deterioration in ACE in PD patients, decrease in motor } \\
\text { potential and inrease in frontotemporal connectivity; } \\
\text { changes in motor potentials were correlated with } \\
\text { volume and atrophy of the basal ganglia }\end{array}$ \\
\hline $\begin{array}{l}\text { Rodrigues et al. } \\
\text { (53) }\end{array}$ & $\begin{array}{l}31 \text { PD patients, } 61 \\
\text { healthy controls }\end{array}$ & Action fluency & Deterioration in PD \\
\hline $\begin{array}{l}\text { Garcia et al. } \\
(54)\end{array}$ & $\begin{array}{l}51 \text { PD patients, } 50 \\
\text { healthy controls }\end{array}$ & Spontaneous speech & $\begin{array}{l}\text { No difference in total number of words, nouns, } \\
\text { action or non-action verbs; but less refining of action } \\
\text { containing issues }\end{array}$ \\
\hline $\begin{array}{l}\text { Salmazo-Silvo } \\
\text { et al. ( } 55 \text { ) }\end{array}$ & $\begin{array}{l}19 \text { PD patients, } 32 \\
\text { healthy controls }\end{array}$ & $\begin{array}{l}\text { Semantic fluency, verb fluency, } \\
\text { noun and verb naming }\end{array}$ & $\begin{array}{l}\text { No difference in verbal fluency, verb naming was } \\
\text { worse in PD patients }\end{array}$ \\
\hline $\begin{array}{l}\text { Salmazo-Silvo } \\
\text { et al. ( } 55)\end{array}$ & $\begin{array}{l}21 \text { PD patients, } 42 \\
\text { healthy controls }\end{array}$ & $\begin{array}{l}\text { Semantic association for noun } \\
\text { and verbs }\end{array}$ & $\begin{array}{l}\text { Performance was worse in both tests in PD patients, } \\
\text { but deterioration was obvious in verbs }\end{array}$ \\
\hline
\end{tabular}


Bertella et al. (32) used the picture naming test in patients with early stage PD who had no cognitive deterioration. The picture naming test contains pictures of objects and action. Patients with PD showed worse performance in action naming compared with healthy subjects. The authors suggested that action verbs were associated with more anterior regions than nouns.

Peran et al. (33) used the word generation test in patients with early stage PD who were during ON medication using two intracategory word groups (noun/noun and verb/verb generation) and two intercategory word groups (noun/verb and verb/noun generation). Patients were asked to produce a noun or verb related with the word they heard. Patients with PD were unsuccessful in producing verbs and they made more grammatical mistakes in tasks involving verbs. The researchers suggested that impairment in verb production may be caused by prefrontal cortex dysfunction in patients with PD. However, this study offered no evidence for the two separate theories suggesting that verbs are represented in the brain according to their meanings or grammatical features. The authors suggested that verbs may be related with prefrontal cortex grammatically because of their semantic and syntactic features, and impairment in verb producing in patients with PD may be caused by this relation.

Signorini and Volpato (34) performed cognitive, verbal fluency, and object and action naming tests on patients with PD and healthy controls and followed up these two groups for 24 months. Tests were repeated at 6,12, 18, and 24 months. At first, there was a difference only in action fluency, which is one of the verbal fluency tests, between the patients with PD and healthy controls. This disturbance in action fluency persisted during the follow-up visits. The authors suggested that the disturbance in action fluency might be caused by executive dysfunction because action naming scores were normal in patients with PD.

Cotelli et al. (35) performed various neuropsychological tests and a picture naming test including object and action pictures recruiting patients with early stage PD. Patients with PD showed worse performance in both object and action naming compared with healthy subjects. However, there were also differences between object and action naming tests in patients with PD; action naming was worse than object naming in patients with PD. When these disturbances were evaluated with other neuropsychological tests, a negative correlation was found between disturbance in action naming and visual memory test scores. The authors thought that the complexity of pictures might cause a disturbance in the naming test and suggested that the disturbance in action naming might be caused by subcorticalprefrontal dysfunction in PD.

Boulenger et al. (36) evaluated the performance of patients with PD and healthy controls in a priming effect task. In this task, a lexical judgment test including nouns and verbs was used. Patients with PD were tested during $\mathrm{ON}$ and OFF medication. A priming effect, which was observed in healthy subjects, was not observed in patients with PD during OFF medication; however, it was observed in patients with PD during ON medication. These findings showed that verbs were selectively impaired in patients with PD during OFF medication when the symptoms of the disease are obvious, but when the symptoms were improved with levodopa, performance in verbs became normal, which suggests that the motor system plays a role in verb processing.
Castner et al. (37) performed a study on patients with PD to evaluate the effects of subthalamic nucleus deep brain stimulation (STN-DBS) on the production of nouns and verbs using the method of Peran et al. (33). Patients with PD were tested during $\mathrm{ON}$ and $\mathrm{OFF}$ stimulation conditions. During the OFF stimulation condition, patients with PD showed selective deterioration in verb production compared with healthy subjects. During the on stimulation condition, patients with PD made significantly more mistakes in noun-noun and verbverb conditions compared with healthy controls. In view of these findings, the authors suggested that STN-DBS modulates the frontotemporal network, which is related with word production. During the ON stimulation condition, mistakes in verb production, which were not observed during the OFF stimulation condition, could depend on the small number of words that can be selected. With this finding, the authors concluded that STN-DBS could selectively affect the chosing ability from various competing processes.

Crescentini et al. (38) performed a word production task on patients with during PD ON medication and healthy controls. Differing from the study of Peran et al. (33), their method contained only noun/noun and noun/verb tasks. These tasks were also built to contain conditions such as chosing a response from different options and strong or weak relations between stimulusresponse. Patients with $\mathrm{PD}$ showed worse performance in verb production compared with healthy controls. It was reported that patients with PD made grammatical mistakes during verb production. Also it was reported that the strong relation between stimulus and response had a great effect on performance. This finding might suggest that patients with PD had difficulties in verb production because they could not choose from competing options. It is known that choosing one and eliminating other options is a function of BG and with their findings, the authors suggested that language disturbances in early-stage PD could be caused by the loss of this function.

Peran et al. (39) performed verb production task in PD during ON medication with functional magnetic resonance imaging (fMRI). Stimuli consisted of object pictures grouped as man-made objects and biologic objects that could be manipulated. In the first step, patients were asked to name objects that they saw, and in the second step, they were asked to say a verb that could be used with the object they saw. Patients showed worse performance in the verb production task. Significant activation was observed in the prefrontal cortex, Broca area, and anterior cingulate cortex in fMRI during the verb production task. There was no association between the impairment in the verb production task and the United Parkinson's Disease Rating Scale (UPDRS) scores, but a positive corelation was found between UPDRS scores and activations in bilateral pre- and postcentral gyrus, the left frontal operculum, left supplementary motor area, and right superior temporal cortex. Thus, it was concluded that the frontal cortex played an important role in verb production. Also, the researchers suggested that the cortical network could become active to overcome the verb production deficit, which was caused by the impairment of motor striatal-frontal loops.

Rodriguez-Ferreiro et al. (40) evaluated patients with PD, healthy controls, and patients with Alzheimer's disease. Mini Mental State Examination scores were not different between 
patients with PD and healthy controls and they were lower in patients with Alzheimer's disease, as expected. The healthy controls showed significantly better performance in the picture naming task including nouns and verbs compared with patients with PD and patients with Alzheimer's disease. However, action naming was found to be worse than object naming only in patients with PD. With these findings, the researchers concluded that the motor system played a role in the action-related language processes.

Herrera et al. (41) compared the verbal fluency performance of patients with PD using levodopa and healthy controls. The patients were tested during $\mathrm{ON}$ and OFF medication. Patients with PD during OFF medication produced fewer words in phonemic and verb categories of verbal fluency compared with patients during $\mathrm{ON}$ medication and healthy controls. Also patients with PD during OFF medication produced verbs that were more commonly used in daily life in the action fluency task compared those during ON medication and healthy controls. Patients with PD during ON medication showed similar performance to the healthy controls and produced words with similar frequency. The authors suggested that dopamine played a role in the lexicosemantic system, especially related with word recall.

Herrera et al. (42) used a picture naming task with patients with PD and healthy controls to evaluate the effect of motor content of words on naming. The words were grouped as motor or non-motor verbs in the task. Healthy controls showed similar performance in both groups of words but motor verb naming was impaired in patients with PD. The authors concluded that the brain areas related with action were also related with actionrelated words, which caused impairment in action-related word naming in patients with PD.

In another study, Herrera and Cuetos (43) investigated the effect of dopaminergic treatment on action and non- action verb naming in patients with PD. Patients during OFF medication named action verbs more slowly than patients during ON medication, but there was no difference in non-action verb naming between them. This finding shows the positive effect of dopaminergic treatment on action verbs.

Silveri et al. (44) performed naming and reading tasks on patients with PD with bilateral STN-DBS and healthy controls to evaluate the effect of the stimulation of STN on nouns and verbs. Healthy controls showed better performance compared with patients with PD in the action naming task. Both healthy controls and patients with PD showed worse performance in action naming compared with noun naming. Patients with PD were significantly slower than healthy controls in action naming. During the $\mathrm{ON}$ stimulation condition, patients with PD showed better performance in terms of accuracy and response time and made fewer semantic mistakes in the object and action naming task. Also, during the ON stimulation condition, action naming was more improved than object naming. In the reading task, accuracy was similar between two groups but there was slowing in response time in patients with PD compared with healthy controls. However, the difference between object and action naming was not observed in noun and verb reading between patients with PD and healthy controls. This study showed that STN-DBS, which has an important place in the treatment of PD, also has a positive effect on actionrelated language.
Fernandino et al. (45) evaluated the differences between action verbs and abstract verbs in PD. A lexical judgments test containing a priming effect and semantic similarity judgments test was performed. Patients with PD showed worse performance in both tests for action verbs, in particular compared with healthy controls. The authors concluded that the motor system did not play role in verbs in general, but played a specific role in action verb processing.

Fernandino et al. (46) performed a task in which patients tried to decide whether sentences were meaningful. Meaningful sentences were grouped as sentences containing action in its real sense, metaphoric action without idiomatic expression, idiomatic action, and abstract action. Action-related sentences were created with the same action verbs describing hand/arm movements. Responses to sentences containing real action verbs and idiomatic verbs were slower compared with responses to sentences containing abstract verbs in patients with PD. Such a difference was not observed in healthy controls. The authors suggested that the sensorimotor system played an important role in action-related semantic processing including metaphoric action language.

Ibanez et al. (47) used an action-sentence compatibility effect (ACE) paradigm in which patients with PD performed an action and then decided whether the given sentences were related with the action they performed. The ACE paradigm leads to a delay in response time in incompatible action-sentence couples compared with compatible action-sentence couples. During the task, patients listened to sentences including opened hand verbs (e.g., to clap), closed hand verbs (e.g., to use a hammer) and neutral verbs (no hand movement, such as to visit) and they were asked to respond to every sentence by pushing the button with their hands in an opened or closed position. ACE was reduced in patients with PD compared with healthy controls. This finding could not be explained by general cognitive impairment or executive dysfunction. Also, there was a strong correlation between ACE performance and measures of action-related language processes. These findings supported the theory that there was impairment in action-related language in PD independent of cognitive impairment.

Kemmerer et al. (48) performed a semantic similarity judgments test including action and non-action verbs on patients with PD during $\mathrm{ON}$ and OFF medication and healthy subjects. $\mathrm{PD}$ patients during $\mathrm{ON}$ and $\mathrm{OFF}$ medication gave correct responses as similar with the healthy subjects. However, the reaction time was longer in patients with $\mathrm{PD}$ regardless of $\mathrm{ON}$ and OFF medication in both action and non-action verbs compared with healthy controls. Although a slowing in verb processing was observed in patients with PD, there was no difference between action and non-action verbs, no shown effect of dopamine, and no difference in terms of accuracy, thus contradicting the Embodied Motor Theory. Also, only verbs were used and there was no comprasion between nouns and verbs in the study, which does not allow any assumptions on whether the slowness was specific to verbs.

Peran et al. (49) performed fMRI on patients with PD during $\mathrm{ON}$ and OFF dopaminergic treatment states to investigate the effect of levodopa on action-related language. Participants were given three tasks; naming objects that they saw on the screen, producing a verb that could be used with 
the object they saw, and imagining the action in their minds. Patients made more mistakes in verb production compared with object naming regardless of $\mathrm{ON}$ and $\mathrm{OFF}$ dopaminergic treatment states. Verb producing elicited more activation in the left prefrontal cortex and left precuneus compared with object naming, and mental imagery of the action caused more activation in the bilateral prefrontal cortex and bilateral parietooccipital junction compared with object naming. fMRI showed differences in prefrontal areas between verb producing and object naming tasks and in the thalamus and premotor areas between mental imagery of the action and object naming in patients with PD with ON dopaminergic treatment state compared with OFF state. However, in patients with PD with OFF dopaminergic treatment state compared with ON state, fMRI showed no difference between verb producing and object naming, or between mental imagery of the action and object naming. These findings suggested that dopaminergic treatment modulates brain activations associated with actionrelated language. According to the researchers, involvement of motor and premotor areas in cerebral reorganization suggests that the putaminal-motor loop plays a role in verb processing.

Cardona et al. (50) used an ACE paradigm in patients with neuromyelitis optica (NMO), acute transverse myelitis (ATM), and early-stage PD to investigate the effects of the motor system in brain and the peripheral motor system directly related with muscle and skeletal activity separately on action-related language. Three healthy control groups for each patient group were also included in the study. NMO and ATM represent peripheral motor system, whereas PD represents the motor system in the brain. Neuropsychological tests showed impairment in short-term memory, slowing in information processing, and partial executive dysfunction in patients with NMO, whereas there was no cognitive impairment in patients with ATM. There was impairment in working memory and action verbs in patients with PD. Patients with PD showed deterioration in ACE, whereas patients with ATM and NMO did not. This study showed that action-related language was associated with the motor system in brain but not with peripheral motor systems.

Bocanegra et al. (51) comprehensively investigated actionrelated language, cognitive functions, and syntax in patients with PD. PD patients showed significant deterioration in executive functions, syntactic analysis, verb naming, verb and object identification compared with healthy controls. Deterioration in syntactic analysis and object identification was found to be related with executive dysfunction, whereas deterioration in verb naming and verb identification were independent of executive dysfunction. These findings suggested that verb processes apart from other language processes and executive functions could be associated with BG.

Melloni et al. (52) used an ACE paradigm in patients with early-stage PD and healthy controls. The important part of the study was that the cortical recordings of the motor potential, functional connectivity measures, and structural analysis of the BG through voxel-based morphometry were investigated on top of behavioral data. Patients with PD exhibited impaired ACE, reduced motor potential, and aberrant frontotemporal connectivity compared with healthy controls. Motor potential changes during the ACE paradigm were correlated with the volume and atrophy of BG. These findings suggested that a cortico-subcortical network involving the BG could play a role in action-related language. The authors claimed that impairment in action verbs could be a neurocognitive marker for early-stage PD.

Rodrigues et al. (53) investigated action-related language impairment in PD using verbal fluency tests. There was no difference between patients with PD and healthy controls in terms of cognitive tests and phonemic and semantic fluency tests. However, patients with PD exhibited significant impairment in the action fluency test compared with healthy controls. As shown in the study of Ibanez et al. (47), observation of impairment in action verbs before cognitive impairment suggested that action-related language processing was independent of cognitive functions.

Garcia et al. (54) investigated action verb production in patients with PD to evaluate the effect of PD on spontaneous discourse. Patients with PD do not report problems with their speech except for having motor language disturbances, which highlights the importance of using spontaneous discourse production tests rather than artificial tests to assess language impairments. Language production in patients with PD was similar to healthy controls. However, patients with PD tended to refer to less action-related issues; instead they preferred to use qualifier words in conversation more.

Salmazo-Silvo et al. (55) used verbal fluency tasks involving nouns and verbs, naming and semantic association tasks in patients with PD and healthy controls to investigate the Embodied Cognition Theory. Both groups exhibited similar performance in verbal fluency tasks. However, patients with PD showed impairment in verbs in the naming task. Impairment in verbs was not detected in only lexical judgments tasks, but also in the semantic association task, which supports the idea that verbs are related with the prefrontal cortex, which is affected in PD. This association may not only arise from the action content in the sense of verbs, but could be caused by the grammatical features of verbs. This may support a more flexible embodied theory suggesting that other areas of the brain, in addition to motor areas are recruited during action-related language.

In summary, most studies on action-related language in patients with PD have shown that processes related with action verbs are impaired and this impairment is not always related with other cognitive or language functions. These results suggest that BG structures are important in action-related language. Cortical and subcortical motor areas related with action are also associated with action-related language, but this relation is not observed in peripheral motor systems. The effects of motor system impairment in PD on action-related language can provide important data about the neural basis of action-related language.

\section{Basal Ganglia in Action-related Language}

The first studies on BG proposed that BG were a secondary component of the motor system and had only motor functions. It was claimed that BG structures only had roles in slow movement and selection and inhibition of motor programs in competition with each other (56). Non-motor functions of BG were reported over time. The recruitment of BG structures during award processes, implicit learning, and habit producing has been known 
for a while now (57). Various studies have also shown that BG structures are implicated in cognitive processes and lesions of BG cause cognitive impairment (58).

Houk (59) proposed that in terms of embodied motions and ideas, BG had a modulating effect on the cortex and BG affected language functions. Especially in terms of syntactic processes, the role of BG in language is interesting for researchers (60). This role of BG is supported by brain imaging studies. Imaging studies on the frontostriatal network have shown the role of BG in semantic processes (4). Kotz et al. (61) showed that BG structures were involved in both semantic and syntactic processes because BGthalamo-cortical networks were activated during semantic and syntactic data integration.

Syntactic errors are associated with increased activation in the left caudate nucleus (62). Phonologic errors increase activation in the left caudate nucleus, whereas faster phonologic processing is associated with increased activation in the left putamen (63). Abdullaev and Melnichuk (64) showed that neuronal firing increased in the head of the caudate nucleus in the early phase of semantic processing and in the late phase of phonologic processing, which is not related with motor output and is only related with language. Ullman (65) proposed that BG may be a part of the procedural system that occurs in the conversion of phonemes to words.

Lehericy et al. (66) showed that the putamen was primarily connected with motor and premotor areas. It is also connected with the posterior prefrontal cortex as shown by diffusion tensor imaging. The posterior frontal cortex is also related with phonologic segmentation and articular control (67). The study by Abdullaev and Melnichuk (64) also suggested that BG worked together with the motor and prefrontal cortex during integration of motor and semantic information. The important role of BG in motor control, habit acquisition, and initiation of movement suggests that the BG-thalamocortical loop is one of the neuronal mechanisms that assist the initiation of motor representation underlying semantic integration and action verb processing.

Different parts of BG are involved in semantic and syntactic language processes. BG structures play active roles in motor functions and have intense connections with the frontal cortex, which indicates that these structures are active in action-related language associated with the motor system.

\section{Conclusion}

It is clear that BG play an important role in language functions. However, this role must be examined in more detail with imaging and patient groups. The subcortical structures that are impaired make PD an interesting disorder to investigate how impairment of BG affects action-related language.

Numerous cortical connections of BG are known to be activated during language functions. According to the Embodied Cognition Theory, action-related language is formed in action-related areas of the brain and this theory can be tested through BG studies. Determining the functional organization of the motor-language network can show the role of BG on action-related language. Studies that set out to show changes in action-related language in patients with PD under different treatment regimens, in patients with different movement disorders, and imaging studies on healthy controls as well as patients with movement disorders will serve as pathfinders in the search for the location of action-related language in the brain.

\section{Ethics}

Peer-review: Externally and internally peer-reviewed.

\section{Authorship Contributions}

Concept: E.B., M.C.A., Design: E.B., M.C.A., Data Collection or Processing: E.B., Analysis or Interpretation: E.B., M.C.A., Literature Search: E.B., Writing: E.B., M.C.A.

Conflict of Interest: No conflict of interest was declared by the authors.

Financial Disclosure: The authors declared that this study has received no financial support.

\section{References}

1. Dorsey ER, Constantinescu R, Thompson P, Biglan KM, Holloway RG, Kieburtz K, Marshall FJ, Ravina BM, Schifitto G, Siderowf A, Tanner CM. Projected number of people with Parkinson disease in the most populous nations, 2005 through 2030. Neurology 2007;68:384-386.

2. Durmus H, Gokalp MA, Hanagasi HA. Prevalence of Parkinson's disease in Baskale, Turkey: a population based study. Neurol Sci 2015;36:411413 .

3. Massano J, Bhatia KP. Clinical Approach to Parkinson's Disease: Features, Diagnosis, and Principles of Management. Cold Spring Harb Perspect Med 2012;2:a008870.

4. Cardona JP, Gershanik O, Gelormini-Lezama C, Houck AL, Cardona S, Kargieman L, Trujillo N, Arevalo A, Amoruso L, Manes F, Ibanez A. Actionverb processing in Parkinson's disease: new pathways for motor-language coupling. Brain Struct Funct 2013; 218:1355-1373.

5. Gallese V, Sinigaglia C. What is so special about embodied simulation? Trends Cogn Sci 2011;15:512-519.

6. Arevalo AL, Baldo JV, Dronkers NF. What do brain lesions tell us about theories of embodied semantics and the human mirror neuron system? Cortex 2012; $48: 242-254$.

7. Tranel D, Kemmerer D, Adolphs R, Damasio H, Damasio AR. Neural correlates of conceptual knowledge for actions. Cogn Neuropsychol 2003;20:409-432.

8. Saygin AP, Wilson SM, Dronkers NF, Bates E. Action comprehension in aphasia: linguistic and non-linguistic deficits and their lesion correlates. Neuropsychologia 2004;42:1788-1804.

9. Bak TH, Yancopoulou D, Nestor PJ, Xuereb JH, Spillantini MG, Pulvermüller F, Hodges JR. Clinical, imaging and pathological correlates of a hereditary deficit in verb and action processing. Brain 2006;129:321332.

10. Aarsland D, Kurz MW. The epidemiology of dementia associated with Parkinson's disease. Brain Pathol 2010;20:633-639.

11. Janvin CC, Larsen JP, Salmon DP, Galasko D, Hugdahl K, Aarsland D Cognitive profiles of individual patients with Parkinson's disease and dementia: comparison with dementia with lewy bodies and Alzheimer's disease. Mov Disord 2006;21:337-342.

12. Goetz CG, Emre M, Dubois B. Parkinson's disease dementia: definitions, guidelines, and research perspectives in diagnosis. Am Neurol 2008;64(Suppl 2):81-92.

13. Aarsland D, Andersen K, Larsen JP, Lolk A, Kragh-Sorensen P. Prevalence and characteristics of dementia in Parkinson disease: an 8-year prospective study. Arch Neurol 2003;60:387-392.

14. Zgaljardic DJ, Borod JC, Foldi NS, Mattis P. A review of the cognitive and behavioral sequelae of Parkinson's disease: relationship to frontostriatal circuitry. Cogn Behav Neurol 2003;16:193-210.

15. Pahwa R, Paolo A, Tröster A, Koller W. Cognitive impairment in Parkinson's disease. Eur J Neurol 1998;5:431-441.

16. Raskin SA, Borod JC, Tweedy J. Neuropsychological aspects of Parkinson's disease. Neuropsychol Rev 1990;1:185-221. 
17. Ridenour TA, Dean RS. Parkinson's disease and Neuropsychological assessment. Int J Neurosci 1999;99:1-18.

18. Ding W, Ding LJ, Li FF, Han Y, Mu L. Neurodegeneration and cognition in Parkinson's disease: a review. Eur Rev Med Pharmacol Sci 2015;19:22752281.

19. Taylor AE, Saint-Cyr JA, Lang AE. Frontal lobe dysfunction in Parkinson's disease. Brain 1986;109:845-883.

20. Sullivan EV, Sagar HJ. Double dissociation of short-term and long-term memory for nonverbal material in Parkinson's disease and global amnesia. A further analysis. Brain 1991;114:893-906.

21. Bruna O, Junque C, Vendrell P, Roig C, Grau-Veciana JM. Memory changes in Parkinson's disease. Relation with clinical variables. Neurologia 1992;7:55-60.

22. Allain H, Lieury A, Thomas V, Reymann JM, Gandon JM, Belliard S. Explicit and procedural memory in Parkinson's disease. Biomed Pharmacother 1995;49:179-186.

23. Aronson AE. Clinical Voice Disorders. New York: Thieme-Stratton, 1990.

24. Mawdsley C, Gamsu CV. Periodicity of speech in Parkinsonism. Nature 1971;231:315-316.

25. Tröster AI, Fields JA, Testa JA, Paul RH, Blanco CR, Hames KA, Salmon DP, Beatty WW. Cortical and subcortical influences on clustering and switching in the performance of verbal fluency tasks. Neuropsychologia 1998;36:295304.

26. Troyer AK, Moscovitch M, Winocur G, Leach L, Freedman M. Clustering and switching on verbal fluency tests in Alzheimer's and Parkinson's disease. J Int Neuropsychol Soc 1998;4:137-143.

27. Grossman M. Sentence processing in Parkinson's disease. Brain Cogn 1999;40:387-413.

28. Grossman M, Crino P, Reivich M, Stern MB, Hurtig HI. Attention and sentence processing deficits in Parkinson's disease: The role of anterior cingulate cortex. Cereb Cortex 1992;2:513-525.

29. Pulvermüller F. Brain mechanisms linking language and action. Nat Rev Neurosci 2005;6:576-582.

30. Hauk O, Shtyrov Y, Pulvermüller F. The time course of action and actionword comprehension in the human brain as revealed by neurophysiology. $\mathrm{J}$ Physiol Paris 2008;102:50-58.

31. Grafton ST. Contributions of functional imaging to understanding parkinsonian symptoms. Curr Opin Neurobiol 2004;14:715-719.

32. Bertella L, Albani G, Greco E, Priano L, Mauro A, Marchi S, Bulla D, Semenza C. Noun verb dissociation in Parkinson's disease. Brain Cogn 2002;48:277280.

33. Peran P, Rascol O, Demonet JF, Celsis P, Nespoulous JL, Dubois B, Cardebat D. Deficit of verb generation in nondemented patients with Parkinson's disease. Mov Disord 2003;18:150-156.

34. Signorini M, Volpato C. Action fluency in Parkinson's disease: a follow-up study. Mov Disord 2006;21:467-472.

35. Cotelli M, Borroni B, Manenti R, Zanetti M, Arevalo A, Cappa SF, Padovani A. Action and object naming in Parkinson's disease without dementia. Eur J Neurol 2007;14:632-637.

36. Boulenger V, Mechtouff L, Thobois S, Broussolle E, Jeannerod M, Nazir TA. Word processing in Parkinson's disease is impaired for action verbs but not for concrete nouns. Neuropsychologia 2008;46:743-756.

37. Castner JE, Chenery HJ, Silburn PA, Coyne TJ, Sinclair F, Smith ER, Copland DA. Effects of subthalamic deep brain stimulation on noun/verb generation and selection from competing alternatives in Parkinson's disease. J Neurol Neurosurg Psychiatry 2008;79:700-705.

38. Crescentini C, Mondolo F, Biasutti E, Shallice T. Supervisory and routine processes in noun and verb generation in nondemented patients with Parkinson's disease. Neuropsychologia 2008;46:434-447.

39. Peran P, Cardebat D, Cherubini A, Piras F, Luccichenti G, Peppe A, Caltagirone C, Rascol O, Demonet JF, Sabatini U. Object naming and action-verb generation in Parkinson's disease: a fMRI study. Cortex 2009;45:960-971.

40. Rodriguez-Ferreiro J, Menendez M, Ribacoba R, Cuetos F. Action naming is impaired in Parkinson disease patients. Neuropsychologia 2009;47:32713274 .

41. Herrera E, Cuetos F, Ribacoba R. Verbal fluency in Parkinson's disease patients on/off dopamine medication. Neuropsychologia 2012;50:36363640 .
42. Herrera E, Rodriguez-Ferreiro J, Cuetos F. The effect of motion content in action naming by Parkinson's disease patients. Cortex 2012;48:900904.

43. Herrera E, Cuetos F. Action naming in Parkinson's disease patients on/off dopamine. Neurosci Lett 2012;513:219-222.

44. Silveri MC, Ciccarelli N, Baldonero E, Piano C, Zinno M, Soleti F, Bentivoglio AR, Albanese A, Daniele A. Effects of stimulation of the subthalamic nucleus on naming and reading nouns and verbs in Parkinson's disease. Neuropsychologia 2012;50:1980-1989.

45. Fernandino L, Conant LL, Binder JR, Blindauer K, Hiner B, Spangler K, Desai RH. Parkinson's disease disrupts both automatic and controlled processing of action verbs. Brain Lang 2013;127:65-74.

46. Fernandino L, Conant LL, Binder JR, Blindauer K, Hiner B, Spangler K, Desai RH. Where is the action? Action sentence processing in Parkinson's disease. Neuropsychologia 2013;51:1510-1517.

47. Ibanez A, Cardona JF, Dos Santos YV, Blenkmann A, Aravena P, Roca M, Hurtado E, Nerguizian M, Amoruso L, Gomez-Arevalo G, Chade A, Dubrovsky A, Gershanik O, Kochen S, Glenberg A, Manes F, Bekinschtein T. Motor-language coupling: direct evidence from early Parkinson's disease and intracranial cortical recordings. Cortex 2013;49:968-984.

48. Kemmerer D, Miller L, MacPherson MK, Huber J, Tranel D. An investigation of semantic similarity judgments about action and non-action verbs in Parkinson's disease: implications for the Embodied Cognition Framework. Front Hum Neurosci 2013;7:146.

49. Peran P, Nemmi F, Meligne D, Cardebat D, Peppe A, Rascol O, Caltagirone C, Demonet JF, Sabatini U. Effect of levodopa on both verbal and motor representations of action in Parkinson's disease: A fMRI study. Brain Lang 2013;125:324-329.

50. Cardona JF, Kargieman L, Sinay V, Gershanik O, Gelormini C, Amoruso L, Roca M, Pineda D, Trujillo N, Michon M, Garcia AM, Szenkman D, Bekinschtein T, Manes F, Ibanez A. How embodied is action language? Neurological evidence from motor diseases. Cognition 2014;131:311322.

51. Bocanegra Y, Garcia AM, Pineda D, Buritica O, Villegas A, Lopera F, Gomez D, Gomez-Arias C, Cardona JF, Trujillo N, Ibanez A. Syntax, action verbs, action semantics, and object semantics in Parkinson's disease: Dissociability, progression, and executive influences. Cortex 2015;69:237-254.

52. Melloni M, Sedeno L, Hesse E, Garcia-Cordero I, Mikulan E, Plastino A, Marcotti A, Lopez JD, Bustamante C, Lopera F, Pineda D, Garcia AM, Manes F, Trujillo N, Ibanez A. Cortical dynamics and subcortical signatures of motor-language coupling in Parkinson's disease. Sci Rep 2015;5:11899.

53. Rodrigues IT, Ferreira JJ, Coelho M, Rosa MM, Castro-Caldas A. Action verbal fluency in Parkinson's patients. Arq Neuropsiquiatr 2015;73:520-525.

54. Garcia AM, Carrillo F, Orozco-Arroyave JR, Trujillo N, Vargas Bonilla JF, Fittipaldi S, Adolfi F, Nöth E, Sigman M, Fernandez Slezak D, Ibanez A, Cecchi GA. How language flows when movements don't: An automated analysis of spontaneous discourse in Parkinson's disease. Brain Lang 2016;162:19-28.

55. Salmazo-Silva H, Parente MA, Rocha MS, Baradel RR, Cravo AM, Sato JR, Godinho F, Carthery-Goulart MT. Lexical-retrieval and semantic memory in Parkinson's disease: The question of noun and verb dissociation. Brain Lang 2017;165:10-20.

56. Mink JW, Thach WT. Basal ganglia intrinsic circuits and their role in behavior. Curr Opin Neurobiol 1993;3:950-957.

57. Yin $\mathrm{HH}$, Knowlton BJ. The role of the basal ganglia in habit formation. Nat Rev Neurosci 2006;7:464-476.

58. Leisman G, Melillo R. The basal ganglia: motor and cognitive relationships in a clinical neurobehavioral context. Rev Neurosci 2013;24:9-25.

59. Houk JC. Agents of the mind. Biol Cybern 2005;92:427-437.

60. Booth JR, Wood L, Lu D, Houk JC, Bitan T. The role of the basal ganglia and cerebellum in language processing. Brain Res 2007;1133:136-144.

61. Kotz SA, Schwartze M, Schmidt-Kassow M. Non-motor basal ganglia functions: a review and proposal for a model of sensory predictability in auditory language perception. Cortex 2009;45:982-990.

62. Moro A, Tettamanti M, Perani D, Donati C, Cappa SF, Fazio F. Syntax and the brain: disentangling grammar by selective anomalies. Neuroimage 2001;13:110-118. 
63. Tettamanti M, Buccino G, Saccuman MC, Gallese V, Danna M, Scifo P, Fazio F, Rizzolatti G, Cappa SF, Perani D. Listening to action-related sentences activates fronto-parietal motor circuits. J Cogn Neurosci 2005;17:273-281.

64. Abdullaev YG, Melnichuk KV. Cognitive operations in the human caudate nucleus. Neurosci Lett 1997;234:151-155.

65. Ullman MT. The declarative/procedural model of lexicon and grammar. J Psycholinguist Res 2001;30:37-69.
66. Lehericy S, Ducros M, Krainik A, Francois C, Van de Moortele PF, Ugurbil K, Kim DS. 3-D diffusion tensor axonal tracking shows distinct SMA and pre-SMA projections to the human striatum. Cereb Cortex 2004;14:13021309.

67. Poldrack RA, Wagner AD, Prull MW, Desmond JE, Glover GH, Gabrieli JD. Functional specialization for semantic and phonological processing in the left inferior prefrontal cortex. Neuroimage 1999;10:15-35. 